\title{
What is the situation with Personnel in Life Sciences?
}

$\mathrm{T}$ he field of "Living Systems" is a priority in the Scientific and Science Education Personnel FTP, which is evident from the statistical data on the event Conduct of Scientific Research by Educational Scientific Center Staff (Table 1).

The overall level of competition in 2009 was 5.1 applications per grant. For comparison, in 2009 the average level of competition in the "nanotechnology and nanomaterials" field was 8 applications per grant.

Interestingly, judging by the first stages of the "Living Systems" in 2010, competition has increased as compared to 2009; however, the average size of a contract in 2010 is much smaller (this is probably because of the inadequacies in the governmental purchases legislature). The increased competition is due to the increasing phenomenon of "price dumping" applications which use the flaws of the Federal Law № 94 on Government Purchases and which leads to the breaking-up of government funds into ever smaller grants. In practice, the average amount of a grant in 2010 is 1.5-2 times smaller than was planned

Table 1.

\begin{tabular}{|c|c|c|}
\hline Name of the indicator & 2009 & \multicolumn{2}{|c|}{ Event 1.1} \\
\cline { 2 - 3 } & 421 & $2010^{*}$ \\
\hline Number of application (Life Sciences) & 82 & 333 \\
\hline Number of supported ESC projects (Life Sciences) & 377.9 \\
\hline Overall amount of funds, million rubles & 986.0 & - \\
\hline In 2009 & 312.6 & 126.0 \\
\hline In 2010 & 353.0 & 8.8 \\
\hline Average size of contract, million rubles & 12.0 & - \\
\hline In 2009 & 3.8 & 2.9 \\
\hline In 2010 & 4.3 & 12.5 \\
\hline In 2009 & 15.0 & - \\
\hline In 2010 & 5.0 & 4.2 \\
\hline Maximum size of contract, million rubles & 5.0 & \\
\hline In 2009 & 6.0 & \\
\hline In 2010 & 0.5 & \\
\hline
\end{tabular}

Table 2

\begin{tabular}{|c|c|c|c|c|c|c|}
\hline \multirow[t]{2}{*}{ Theme groups } & \multicolumn{2}{|c|}{ Competition } & \multicolumn{2}{|c|}{ Number of projects } & \multicolumn{2}{|c|}{ Number of applications } \\
\hline & 2009 & 2010 & 2009 & 2010 & 2009 & 2010 \\
\hline 141 General biology and genetics & 2.4 & 7.8 & 12 & 4 & 29 & 31 \\
\hline 142 Physico-chemical biology & 2.6 & 6.2 & 12 & 5 & 31 & 31 \\
\hline 143 Fundamental medicine & 4.9 & 5.5 & 19 & 14 & 94 & 77 \\
\hline 201 Biocatalytic technology & 4.5 & 11.5 & 4 & 2 & 18 & 23 \\
\hline 202 Biomedical protection technologies & 9.0 & 9.3 & 20 & 14 & 179 & 130 \\
\hline 203 Genomic technology & 5.0 & 10.3 & 3 & 4 & 15 & 41 \\
\hline 204 Cellular technology & 5.0 & & 3 & - & 15 & - \\
\hline 205 Bioengineering & 3,3 & & 4 & - & 13 & - \\
\hline 206 Bioinformatic technology & 7,0 & & 2 & - & 14 & - \\
\hline 209 Creation of biocompatible materials & 4,3 & & 3 & - & 13 & - \\
\hline Average $\backslash$ Amount & 5.1 & 7.7 & 82 & 43 & 421 & 333 \\
\hline
\end{tabular}


by the authors of the FTP project during its development.

Table 2 shows the distribution of applications and contracts between fields in the section of Living Systems.

Data on the affiliation of the winning organizations are also of some interest. If it were not for the flaws of the law on governmental purchases, these data could be considered to be a realistic rating of Life Sciences centers affiliated with various agencies. However, the current data are not as valuable as that.

Notably, MSU, which won 7 ESC grants in 2009, won only one in 2010 .
Nevertheless, this university is still the leader in the number of ESCs among all participating organizations.

Table 4 shows the 15 most active participants in the ESC grant competition in the field of Living Systems in 2009-2010.

As we can see, 11 of the 15 organizations which applied for more than 8 grants are higher educational institutions. However, the success ratio (which indirectly reflects the quality and scientific level of the presented projects) is higher for research institutes of the Biology Division of RAS as compared to universities, research institutes of the other RAS divisions and other agencies. The RAS Institute of Molecular Biology and RAS Institute of Gene Biology won two grants each after having applied for three each Identical results ( 2 contracts per 3 applications) were also obtained by other acknowledged biological centers: The Pushkino State University, Research Institute of Physico-Chemical Medicine, and others.

In conclusion, we list the organizations with the most funding for their contracts according to the results of the completed competitions in 2010 (Table 5):
Table 3.

\begin{tabular}{|c|c|}
\hline $\begin{array}{l}\text { Higher educational facilities of the } \\
\text { Ministry of Education (RosObr) }\end{array}$ & 42 \\
\hline RAS & 38 \\
\hline RAMS & 18 \\
\hline $\begin{array}{l}\text { Higher educational facilities of the } \\
\text { Ministry of Health and institutions } \\
\text { of its agencies }\end{array}$ & 16 \\
\hline Lomonosov MSU & 8 \\
\hline $\begin{array}{l}\text { Russian Academy of Agricultural } \\
\text { and Livestock Sciences }\end{array}$ & 1 \\
\hline $\begin{array}{l}\text { Ministry of Agriculture and } \\
\text { Livestock }\end{array}$ & 1 \\
\hline $\begin{array}{l}\text { Others (Karpov Scientific Research } \\
\text { Institute of Physical Chemistry) }\end{array}$ & 1 \\
\hline Overall & 125 \\
\hline \multicolumn{2}{|l|}{$\begin{array}{l}* \text { The listed numbers are the number } \\
\text { of supported ESC applications, not the } \\
\text { number of winning organizations }\end{array}$} \\
\hline
\end{tabular}

Table 4

\begin{tabular}{|l|c|c|}
\hline \multicolumn{1}{|c|}{ Organization } & $\begin{array}{c}\text { Number of } \\
\text { applications }\end{array}$ & $\begin{array}{c}\text { Number of } \\
\text { contracts }\end{array}$ \\
\hline Novosibirsk State University & 11 & 3 \\
\hline South Federal University & 10 & 1 \\
\hline Immanuel Kant Russian Governmental University & 10 & 1 \\
\hline RAS Institute of Theoretical and Experimental Biophysics & 9 & 2 \\
\hline Peoples Friendship University of Russia & 9 & 2 \\
\hline $\begin{array}{l}\text { Siberian State Medical University of the Federal Health and } \\
\text { Social Development Agency }\end{array}$ & 9 & 3 \\
\hline Tomsk State University & 9 & 1 \\
\hline Saint-Petersburg State Polytechnical University & 8 & 0 \\
\hline Saint-Petersburg State University & 8 & 2 \\
\hline $\begin{array}{l}\text { RAMS Cardiology Research instate of the Siberian branch of } \\
\text { RAMS }\end{array}$ & 8 & 1 \\
\hline $\begin{array}{l}\text { RAS institute of chemical biology and fundamental medicine of } \\
\text { the Siberian Branch of RAS }\end{array}$ & 8 & 3 \\
\hline $\begin{array}{l}\text { National nuclear research university of the Moscow } \\
\text { Engineering and Physics Institute }\end{array}$ & 8 & 1 \\
\hline $\begin{array}{l}\text { Department of Biology of the M.V. Lomonosov Moscow State } \\
\text { University }\end{array}$ & 8 & 1 \\
\hline RAS Institute of Molecular Genetics & 8 & 3 \\
\hline N.G. Chernishevsky Saratov State University & 2 \\
\hline
\end{tabular}

Table 5.

\begin{tabular}{|c|c|c|}
\hline Organization & Project & $\begin{array}{c}\text { Size of contract } \\
\text { (in millions of rubles). }\end{array}$ \\
\hline $\begin{array}{c}\text { Research Institute of Physico-Chemical } \\
\text { Medicine of the Federal Medico- } \\
\text { biological agency }\end{array}$ & $\begin{array}{c}\text { Study of the paracrine mechanisms behind the effect of mesenchimal } \\
\text { stem cells on the regeneration of tissues using proteome analysis }\end{array}$ & 12.5 \\
\hline $\begin{array}{c}\text { Research Institute of Urology of } \\
\text { the Federal Agency for Highly } \\
\text { Technological Medical Assistance }\end{array}$ & $\begin{array}{c}\text { Development of a comprehensive diagnostic and metric system for } \\
\text { studying the functional activity of the higher an lower urinary ducts }\end{array}$ & 12.0 \\
\hline $\begin{array}{c}\text { Moscow Energetic Institute (Technical } \\
\text { University) }\end{array}$ & $\begin{array}{c}\text { Study of the condition and evolutionary change of biological objects } \\
\text { using remote laser diagnostics }\end{array}$ & 11.0 \\
\hline $\begin{array}{l}\text { K.I. Skryabin Moscow State Academy of } \\
\text { Veterinary Medicine and Biotechnology }\end{array}$ & $\begin{array}{c}\text { Development of innovational diagnostic methods using animal physiol- } \\
\text { ogy and biochemistry as a model for medical use }\end{array}$ & 10.8 \\
\hline $\begin{array}{c}\text { Department of Chemistry of the M.V. } \\
\text { Lomonosov Moscow State University }\end{array}$ & $\begin{array}{c}\text { Development of a method for the molecular monitoring of the spread } \\
\text { of viral infections and for determining the effectiveness of antiviral } \\
\text { compounds in order to create the next generation of therapeutic drugs }\end{array}$ & 10.8 \\
\hline
\end{tabular}

This material was prepared by Ivan Sterligov using materials from the National Personnel Training Foundation (NPTF) Analytical Administration Board of FTPs. The editors thank Alexander Kalyagin (NPTF). 